\title{
Plastic Gothic Frankenstein, Art and the Microplastic Monster
}

\author{
Robyn Glade-Wright
}

James Cook University, Australia

\begin{abstract}
The contamination of life with plastic pollution and humanity's lethargic response to the problem is an unfolding terror: a story of Gothic horror unfolding in contemporary times. The power of Mary Shelley's Gothic novel Frankenstein looms over the current terror of plastic pollution to encourage changes to the materials we create, use and discard. In Frankenstein, a monster was spawned in a process that desecrates the act of creating new life. Similarly, in my work of art Microplastics Found in Human Embryo, the depiction of an embryo is desecrated by plastic contamination. Frankenstein was unable to control his monster, and, denied empathy and love, the monster killed Frankenstein's loved ones and haunted its creator's soul. As microplastics are largely unseen, and increasing exponentially, they are becoming a modern monster. Microplastics can cross the placenta and the blood brain barrier, endangering the life and health of our children, potentially robbing us of progeny, and the future of humankind. Over the past two hundred years, Frankenstein has functioned as a shadowy mnemonic tale, haunting scientists and technologists by reminding them to consider the impacts of their creations. Shelley's message, if applied to the current dangers of the "Age of Plastic", might help us to clean up plastic pollution and embrace sustainable materials. In this spirit, Microplastics Found in Human Embryo reveals a monstrous idea, which aims to help awaken us from complacency and convince humanity to form a relationship which sustains all forms of life on Earth.
\end{abstract}

Keywords: Plastic, Pollution, Environment, Art, Frankenstein, Horror, Monster, Gothic 


\section{Introduction}

The contamination of life - including embryonic life - with plastic pollution and humanity's lethargic response to the problem is a story of Gothic horror unfolding in contemporary times. To magnify the largely unseen horror of small plastic pieces known as microplastics, I created Microplastics Found in Human Embryo from 1000 used plastic drink bottles. ${ }^{1}$ This work of art aims to shock in two ways. Firstly, it suggests the desecration of the act of creating new life due to contamination that causes cell death and harm; and secondly, the work serves as a warning about microplastic contamination of many creatures, which is happening at an increasing rate. After creating and presenting this work of art, I read Mary Shelley's Gothic horror story Frankenstein (1818) and recognised a similar approach to terror. In both the novel and the artwork an abnormal being is created - and once created cannot be controlled. In the novel Victor Frankenstein constructs a hideous monster, while humanity has produced a modern plastic monster - microplastics can harm developing embryos, as is suggested through the work of art (Rojas, 2018). Shelley's seminal Gothic novel Frankenstein helped me to recognise the source of my disquiet and accentuated the urgent need for people to take responsibility for what we manufacture, use and discard. Shelley's Frankenstein has functioned as a cautionary tale over the past two hundred years, reminding scientists to consider the potential outcome of what they create (Cohen, 2018). In a related manner, Microplastics Found in Human Embryo attempts to direct people's attention to the implications of what we produce as the looming terror of plastic pollution may disrupt future life. This is of particular importance in the tropics which contain two thirds of all known plant and animal species, of which approximately one-quarter are classified as threatened with extinction (Kindsvater et al., 2018).

The tropics have long been associated with palm rimmed beaches, warm breezes and the idea of an escape to a verdant paradise (Glade-Wright, 2016). Environmental pollution, by contrast, is associated with big cities replete with pollution from industrial manufacture and cars. However, plastics pollution is not confined to the site of production, the region where it is used or the site of disposal (Rojas, 2018). Waste plastics carried by rivers from land sources to the sea are disrupted by currents and winds across oceans and are deposited on distant shores. Tropical beaches littered with plastic bottles and discarded rubber thongs (flip flops) sully the illusion of being in a pristine environment.

\footnotetext{
${ }^{1}$ Microplastics Found in Human Embryo was introduced by Distinguished Professor Stewart Lockie at the AAS2018 'Life in an Age of Death' Australian Anthropological Society Annual Conference. James Cook University College of Arts, Society and Education, The Cairns Institute, Australia 4-7 December 2018.
} 


\section{The Age of Plastic}

The Western Enlightenment philosophy of world order that strives to supplant traditional beliefs - deemed superstitious and prejudiced - with rational thought and scientific evidence, along with the desire for economic gain, have long shaped our relationship with our planet (Hulme, 2015). This worldview facilitated an unrestricted rise in plastic production associated with a luxury material - ivory. The demand for ivory saw elephant herds decimated in Africa and India. In 1863, in answer to the shortage of ivory used for the manufacture of billiard-balls, a New York manufacturer offered a $\$$ US10,000 prize for a useful substitute. A substitute in the form of plastic was developed by the Hyatt brothers in New York, who had acquired an earlier patent by Englishman Alexander Parkes (Baker, 2018). Forty years later, Leo Baekeland created Bakelite, a low-cost plastic that paved the way for contemporary plastics (Baker, 2018). However, in 1915, Baekeland, known as the "Father of the plastic industry", wrote:

If I had my life to live over again I would not devote it to develop new industrial processes: I would try to add my humble efforts to use Science to the betterment of the human race. I despair of the helterskelter methods of our vaulted homo sapiens, misguided by his ignorance and his politicians. If we continue our ways, there is every possibility that the human race may follow the road of former living races of animals whose fossils proclaim that they were not fit to continue. Religion, laws and morals is not enough. We need more. Science can help us (1915, p. 548).

Baekeland's quote indicates dedication to the potential benefits of science. However, as a result of his invention, as he predicted, "the human race may follow the road of former living races of animals whose fossils proclaim that they were not fit to continue" (Baekeland, 1915, p. 548). The demand for plastics increased during World War II as a substitute for metals which were required for military purposes. Following the war, civilian outlets were rapidly overwhelmed with plastic products, which were "cheap and disposable" (Hammer, Kraak, \& Parsons, 2012, p. 3). The proliferation of plastic was unprecedented due to its versatility, durability and the low cost of manufacture. Its production surpassed that of metals in the US in 1979 (Hammer et al., 2012), and plastic swiftly became a cheap, disposable commodity, and a form of environmental pollution.

In this "Age of Plastic," almost all of the 8.3 billion tonnes ever created still exists and three-quarters of this is plastic waste (Waring, Harris, \& Mitchell, 2018, p. 64). Plastics are virtually indestructible. They do not biodegrade, although in a process 
that can take centuries UV radiation can cause fragmentation into small particles (Diaz, 2018). Despite plastic's durability, around $50 \%$ of plastic is used only once before it is discarded: "... only $9 \%$ has been recycled, $12 \%$ incinerated and $79 \%$ is deposited in landfill or the natural environment" (Mendenhall, 2018, p. 3). Due to this rapid use-cycle, Wilco, Van Sebille and Hardesty have argued, "Global plastic production is increasing exponentially, with a current doubling time of 11 years; thus, between 2015 and 2026, we will make as much plastic as has been made since production began" (2015, p. 11901). The longevity and resilience of plastics, and the toxins they carry, have surfaced as a major environmental problem that was predicted by scientists some fifty years ago. Studies conducted in 1962 identified plastic ingested by marine birds (Wilcox, Van Sebille, \& Hardesty, 2015). In 1978, accurately predicting the current crisis, Ohlendorf, Risebrough and Vermeer wrote, "It is unlikely that any marine birds remain uncontaminated by the synthetic organochlorine compounds that have become ubiquitous pollutants" (1978, p.1).

A photograph published in 1998 of a dead seabird with a stomach full of plastic was a portent of the horror we now face. Plastic pollution has contaminated $90 \%$ of marine bird species and $95 \%$ of birds are impacted within each species (Wilcox, Van Sebille, \& Hardesty, 2015, p. 11902). In the 1990s, large gyres of plastic were found floating in the ocean, including the Great Pacific Garbage Patch which occupies an area the size of France and Spain combined (Leberton et al., 2018). Rivers carry plastic waste from land sources to the sea, accounting for 70 to $80 \%$ of ocean plastic pollution (Rojas, 2018). As $70 \%$ of all plastics are known to eventually sink, it is suspected that ever increasing amounts are accumulating in seabed sediments (Hammer, Kraak, \& Parsons, 2012). Microplastics have been found in around 600 species of marine organisms, including $100 \%$ of turtles, $59 \%$ of whales, and $36 \%$ of seals (Battisti et al., 2019; Rojas, 2018).

Plastic pollution is harmful for all creatures because tiny particles can cross the placenta and the blood brain barrier, altering genes, causing cell death, reducing fertility and lowering rates of survival (Rojas, 2018). Microplastics amass in "the brain, liver and other tissues" where they can "potentially affect the central nervous system and the reproductive system" (Waring, Harris, \& Mitchell, 2018 p. 64). Microplastics from car tyres, synthetic clothing, drink bottles and plastic wrap have contaminated the air, land and water (Besseling et al., 2015). Microplastics in the sea attract toxic chemical hitchhikers and this toxic cocktail enters the food chain where it is consumed by plankton and other marine creatures causing harm such as disease and cell death (Seltenrich, 2015). The contamination caused by microplastics progresses through the food chain, arriving in seafood sold for human consumption (Liebezeit \& Liebezeit, 2014). It is found in fish purchased from markets in the United States and Indonesia, in German beer and in the air in Paris (Rojas, 
2018). Microplastics have also been detected in $83 \%$ of worldwide drinking water, and up to $94 \%$ of drinking water in the USA (Tyree \& Morrison, 2017). In Europe, shellfish consumers ingest 6400 particles of microplastic annually (Van Cauwenberghe \& Janssen, 2014).

Over the past two decades, climate communicators have researched how messages regarding environmental pollution and the perils of climate change can be effectively disseminated to the public in order to foster shifts in behavioural change. Climate communicators lament that several decades of effort by scientists has largely failed to engage and motivate an unreceptive public (Mosser, 2016). In an effort to foster mitigation and adaptation, and to respond to the pressure that human agency has exerted on the Earth's eco-systems, climate communicators have appealed to the arts and humanities to join in a call for change (Corner, Parkhill, Pidgeon \& Vaughan, 2013). Environmental messages delivered by the arts and humanities are recognised for their culturally sensitive forms and broad community appeal (Jacobson, Seavey \& Mueller, 2016). Climate communicators report that messages wrapped in an emotional package have greater impact and a heightened potential for retention than factual presentations of information (Rees-Cheney, 2005; Mosser, 2016). Furthermore, the narrative and visual aspects of messages delivered in the arts and the humanities are recognised as being an effective means of conveying the gravitas of the situation in ways that foster reflection and understanding (Mosser, 2016; Graham 2005). To draw attention to plastic particles that are too small to be seen without magnification, the large art work Microplastics Found in Human Embryo was created to communicate the hidden problem of the contamination of food, water and air.

\section{Microplastics Found in Human Embryo}

To respond to the call for communication regarding the peril of plastic, I thought deeply about the most horrid outcome possible in relation to the blight of plastic pollution. I imagined that a truly shocking idea would be to conflate the elation associated with the conception and promise of new life with the threat of harm from microplastic contamination. Microplastics Found in Human Embryo (Figure 1) was purposely conceived to have an emotional impact. In this work, a plasticised embryo floats in a blue/green umbilical pool - reminiscent of the Great Pacific garbage patch. The work is constructed from one thousand used plastic drink bottles because they were light-weight, low-cost, strong and durable: all the hallmarks of the trouble with plastic. The bottles were collected from my local area in the tropical region of Cairns, Australia, and then coloured and assembled. While constructing the work, my simultaneous research revealed that people around the globe purchase one million drink bottles each minute, $91 \%$ of which are used only once before being discarded 
(Nace, 2017). I chose to portray the work on a large scale in order to communicate the depth of my concern, to emphasise the impending threat of microplastic pollution and to attract attention.

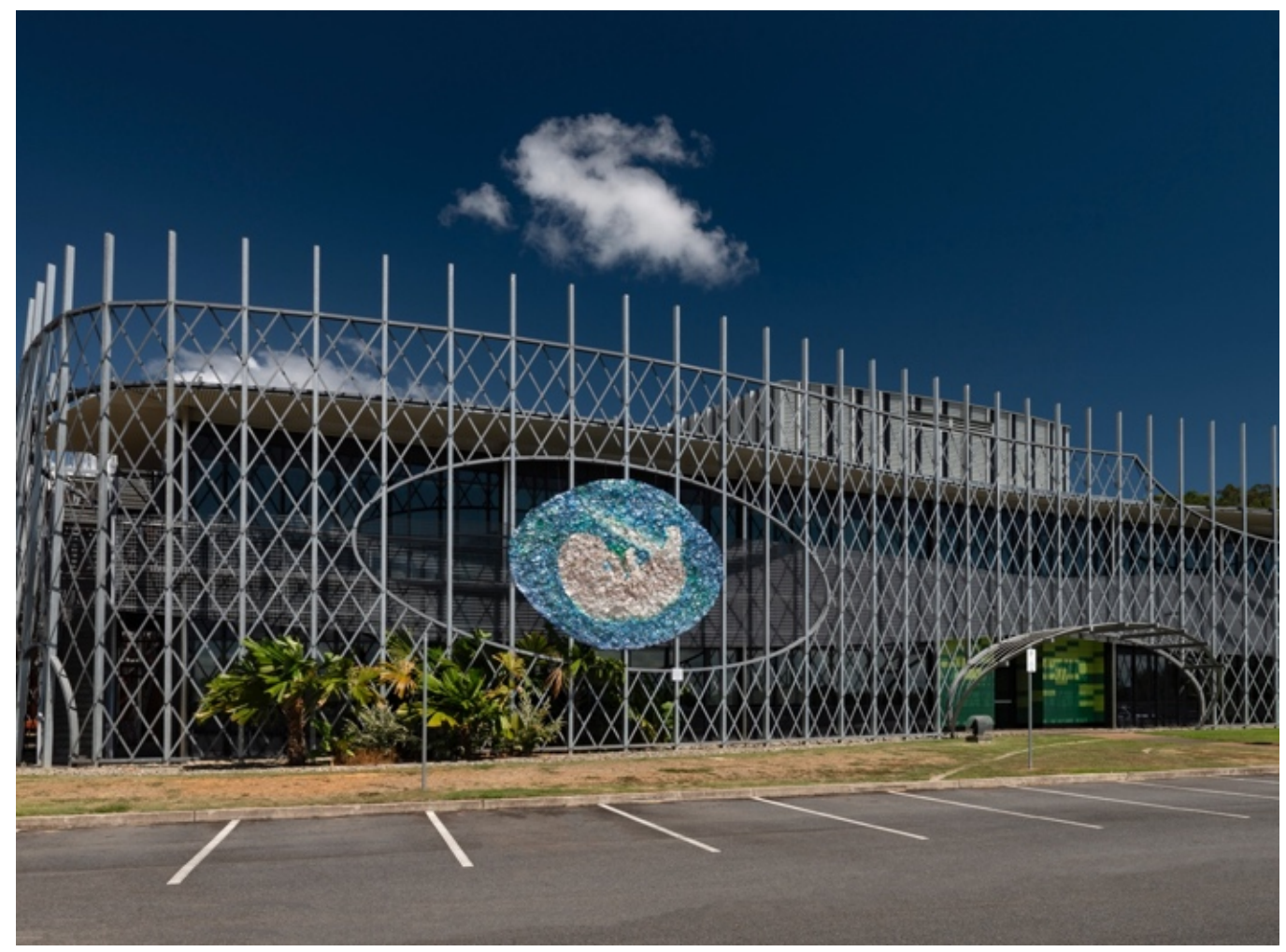

Figure 1. Microplastics Found in Human Embryo, 2018 1000 plastic bottles, cable ties, paint, $360 \times 540 \times 10 \mathrm{~cm}$

I have attempted to wrap the terrifying concept displayed through the artwork in an attractive mantle of harmonious shades of cream, blue and green, a variety of shiny plastic surfaces that glint in the sun. Notwithstanding the difficulty of constructing an embryo from lumpy, plastic bottles, I attempted to create a beautiful object. Beauty has a seductive allure. As expressed by John Armstrong, "The kinds of connections we find in beautiful objects have a deep human significance. They correspond to the profound needs we have - to discover meaningful connections and to unite ourselves with others" (Armstrong, 2004, p. 48). Beauty in this context has been used as a strategy to encourage people to engage in the meaning of the work. Yet, my use of beauty can be considered to be subversive, as the attractive form belies the horror of a new life tainted with plastic. I imagine that, by and large, people do not want to give up the conveniences offered by plastic products and therefore it is easy to ignore the threat of plastic pollution. Thus, the subversive use of beauty aims to attract and hold attention in order to enable the dark message of microplastics crossing the placenta to be communicated from behind a glistening veil. 
Microplastics Found in Human Embryo was created to shock people and to goad environmental adaptation and mitigation. However, having created the work, I found that its message is troublingly prophetic. As more plastics enter our air, food and drinking water, there is an increasing potential that microplastics might cause birth defects, disease, reduced fecundity and/or lower survival rates. While impacts of microplastics on human health have only recently begun to be studied, there is "already overwhelming evidence that exposures to anthropogenic chemicals contribute to adverse effects in animals, such as disorders on reproduction [and the] immune system" (Klar, Gunnarsson, Prevodnik, Hedfors, \& Dahl, 2014). The art work invites the viewer to consider the health issues accrued through anthropogenic chemicals such as those in plastics, or to wonder how long would it take to stop making dangerous forms of plastic, and if it is possible to remove microplastics from the sea, land and air. Viewers may also be inspired to consider how plastics impact reproduction if future progeny were to be deformed by microplastics.

\section{Mary Shelley's Frankenstein}

In Mary Shelley's 1818 novel, Victor Frankenstein could not control his monster, while in my work of art, people are unable or unwilling to control microplastic pollution. Shelley was inspired to write Frankenstein when she and a group of artistic and literary friends were holidaying in Switzerland during the summer of 1816. The group entertained themselves in the evening by inventing ghost stories. One evening, as a form of entertainment, Lord Byron proposed a competition for each to write the best ghost or horror story possible - and Frankenstein was born. Shelley's desire to create the most horrid novel possible resonates with the challenge I set for myself to create the most perturbing work I could in order to communicate my message.

The achievement and the euphoria of creating new life in Shelley's novel rapidly devolves into despair as Frankenstein realises that his creation is a hideous monster, both physically and mentally. Possessed with phenomenal physical powers and free to roam - the fiend was nevertheless deeply unhappy. He desired empathy along with the companionship and love of a mate, all of which Frankenstein denies him. In an act of revenge, the monster murders Frankenstein's loved ones - and the scientist-creator remains haunted by the knowledge of his creation.

Shelley's tale of terror may have been drawn from her life experiences. Shelley's mother died soon after her birth, and she read by her mother's grave as a child. By the time Shelley penned Frankenstein, her half-sister had committed suicide, and Shelley, herself, was outcaste by her family and homeless. She was also a teenager 
in love with a married man, the poet Percy Shelley, with whom she had two babies, both of whom died. One of the babies, Clara, survived eight days and Shelley notes in her journal a dream where the infant came back to life: "I thought if I could bestow animation upon the lifeless matter, I might, in [the] process of time, renew life" (Quoted in Cohen, 2018, p. 149). Shelley's dream to ignite a spark of life resonates with Frankenstein's labour in her novel. The empathy and love of a mother, absent from Shelley's life, were sought by Frankenstein's monster. The desire to create and preserve life are powerful human drives. In Microplastics Found in Human Embryo I have also used the emotive power of this instinct to communicate the threat and horror of plastic pollution by creating a work of art where an embryo is contaminated.

The crucible of creating new life, previously the province of nature, appear as works of horror in Frankenstein and Microplastics Found in Human Embryo. Frankenstein, "having pursued nature to her hiding places", sparks life into an assemblage of cadaver parts, creating a new being, reminiscent of a human (Shelley, 1818, p. 26). As Mishra notes, this "desecration of the divine act" becomes in Shelley's creation of the monster "a de-formation of such magnitude that neither the process nor its product can be grasped" (1994); and yet this is merely the genesis of a trail of terror. The terror that ensues is rich in distilled emotion, detailing human ambition, ingenuity, hubris, pride, and the need to give and receive love. Shelley perceptively "sees" and convincingly portrays the horror of desecrating the act of creating new life. In a similar vein, the contamination of future progeny suggested in Microplastics Found in Human Embryo elicits the torment of a life where babies do not survive and we are robbed of the future of humanity.

Shelley's Frankenstein is a cautionary tale. She deftly identifies the dangers associated with scientists who do not take responsibility for what they create in their laboratories. In addition, she warns scientists to take care to control and contain their creations. This is an unexpected outcome for a story that aimed to primarily entertain, and many scientists relate to the narrative as a clear indication of what they should avoid. Craig Venter, a pioneer in genomics, believes that Frankenstein "affects a lot of people's thinking and fear because it represents this fundamental of 'You don't mess with Mother Nature'" (Cohen, 2018, p. 150). Over the past two hundred years, Frankenstein has been mentioned in 251 scientific papers warning of a hubris that has "haunted science ever since" (Cohen, 2018, p. 148).

In Gothic horror stories, humans regard "the monsters that they encounter as abnormal, as disturbances of the natural order" (Carroll, 1987, p. 52). In Microplastics Found in a Human Embryo we encounter the abnormality of toxic plastic particles potentially impacting a preborn infant's physiology: a threat that is a disturbance to the natural order. The fearfulness of fictional monsters in Gothic 
horror stories "is compounded by revulsion, nausea, and disgust" and "the monster is regarded as threatening and impure" (Carroll, 1987, p. 55). Celebrated author Stephen King asserts "we love the concept of monstrosity" as it provides a demarcation between a healthy life and an anti-life, or between a wholesome or unwholesome life, and functions as "a reaffirmation of the order we all crave as human beings" (Quoted in Morgan, 1998, p. 65). The cultural theorist, Barbara Creed, comments on films set in the thick undergrowth of the tropical jungle which exploit the primitive duality of man. The Creature from the Black Lagoon is an example of a film where the desire of an amphibious human monster for a female scientist entangled the boundaries between a healthy life and an anti-life to horrifying dramatic effect $(2011, \mathrm{p} .135)$. The unhealthy life and the threat of impurity that underpins the monster in Gothic horror surfaces in my work of art. In this plastic Gothic horror, we can no longer be sure that our environment can support a wholesome life.

Art theorist, Ross Gibson, identifies and explains how artistic messages can be highly effective. He notes that art can "make changes in the given or perceived world" and this is why "you know you are encountering art when you are engaging with an intentional process or product that causes surprising transformations in matter or in a moment" (2010, p. 4). The transformations or changes in the given or perceived universe described by Gibson, relate to the three dimensions of our being as identified by the ancient philosopher Plato: "knowledge, emotion and desire" (Teskos, 2018, p. 19). All three are clearly at play in Shelley's novel and entwine to terrible ends. We see in Frankenstein a profound change to the known world, where life is sparked from a collection of cadavers. Frankenstein's monster desires love and family and as he is denied these, avenges himself on his maker. Knowledge, emotion and desire are also entangled in Microplastics Found in a Human Embryo. The threatening idea of an embryo tainted by microplastics causes changes to our perceived world. The work raises questions regarding our knowledge of the safety of our environment and poses a threat to the desire for progeny and the possibility of a human future.

In explaining the manner in which art can generate knowledge, Gibson indicated that the arts "woo two modes of knowing: the implicit and the explicit", (2010, p. 11). Works of art result from a combination of divergent, intuitive, reflective and implicit approaches to problem solving, aligned with rational and analytical methods. This can result in new ways of viewing, revealing and addressing the complex environmental challenges we face. Moreover, because "change occurs first in emotions and second in people's minds", artistic practices "can reveal the limitations of existing knowledge and promote novel ways of responding to climate change" (Galafassi, 2018, p. 73). A feature of works of art is their capacity to function as sites 
for people to contemplate ideas in their own time and in a personal and private manner. Art can contest current knowledge, and "help us to imagine other worlds and possible futures" which can enable us to transform the way we live (Reiss, 2019, p. vii). Works of art, literature and theatre can be performative in the sense that they can reshape consciousness, create new narratives, and generate new knowledge (Reiss, 2019). This is apparent in Shelley's Gothic novel, which initiated the genre of science fiction and the trope of the "mad scientist" (Cohen, 2108). Works of art and literature might invite us to examine our relationship with the Earth and this might drive social and political change (Hulme, 2015). Works such as Microplastics Found in Human Embryo might encourage us to limit plastic production to biodegradable forms and clean up extant plastic pollution. There is hope that art might also help people to establish values that nurture and sustain the planet, which in turn can nurture and sustain all forms of life.

\section{Conclusion}

The task I set for myself - to create the most horrible and upsetting work of art I could envision - is similar to the task Lord Byron assigned to his friends to write the best ghost (or horror) story imaginable. Microplastics Found in Human Embryo enacts a tale of horror that may help us to consider what we value, and to find ways to live and interact with the Earth's eco-systems in a sustainable manner. The power of the Gothic monster may be usefully applied to the current environmental crisis. Frankenstein provides a vision of an unwholesome life and has functioned as a shadowy mnemonic tale, haunting scientists and technologists, by reminding them to consider the impacts of their creations (Cohen, 2018). This message ought to have been heeded over the past century as plastic pollution has become a modern monster. And the threat remains that now that the pollution genie is out of the bottle, it might be impossible to contain. Shelley's message of the desecration of the act of creating new life, if applied to the current dangers of the "Age of Plastic", could help us to embrace sustainable materials and processes and solve the problem of plastic pollution. Works of art such as Microplastics Found in Human Embryo suggest a contemporary Gothic horror that may help to shake us from complacency and convince us to form a sustainable relationship with our planet.

\section{Acknowledgements}

I would like to acknowledge Dr Roger Osborne for his encouragement, insight and faith in my monster. My sincere appreciation is extended to the reviewers of this special issue of eTropic for their sensitive and constructive comments. 
eTropic 18.2 (2019) 'Tropical Gothic: Literary and Creative Works' Special Issue | 78

\section{References}

Armstrong, J. (2004). The Secret Power of Beauty. London, UK: Allen Lane.

Baker, I. (2018). Fifty Materials That Make the World. New York, NY: Springer. DOI: https://doi.org/10.1007/978-3-319-78766-4_6

Baekeland, L. (1915). Applied Chemistry. Science, 42 (1086), 548. DOI: 10.1126/science.42.1086.547

Battisti, C., Staffieri, E., Poeta, G., Sorace, A., Luiselli, L., \& Amori, G. (2019). Interactions between anthropogenic litter and birds: A global review with a 'black-list' of species. Marine Pollution Bulletin, 138, 93-114. DOI: https://doi.org/10.1016/j.marpolbul.2018.11.017

Besseling, E., Foekema, E. M., Van Franeker, J.A., Leopold, M. F., Kuhn, S., Rebolledo, E. L., Hebe, E., Mielke, L., ljzer, J., Kamminga, P., \& Koelmans, A. A. (2015). Microplastic in a macro filter feeder: Humpback whale Megaptera novaeangliae. Marine Pollution Bulletin, 95 (1), 248-252. DOI: https://doi.org/10.1016/j.marpolbul.2015.04.007

Carroll, N. (1987). The Nature of Horror. The Journal of Aesthetics and Art Criticism, 46 (1), 51-59. Retrieved from https://www.jstor.org/stable/431308

Creed, B. (2011). Tropical Malady: Film \& the Question of the Uncanny Human-Animal. eTropic 10, 131-140. DOI: https://doi.org/10.25120/etropic.10.0.2011.3414

Cohen, J. (2018). How a Horror Story Haunts Science. Science, 359 (6372), 148-150. doi: $10.1126 /$ science.359.6372.148

Corner, A., Parkhill, K., Pidgeon, N., \& Vaughan, N. E. (2013). Messing with nature? Exploring public perceptions of geoengineering in the UK. Global Environmental Change, 23 (5), 938-947. doi: org/10.1016/j.gloenvcha.2013.06.002

Diaz, M. (2018). Plastic: Breaking down the Unbreakable, Coastal, 85 (19), 85-113. Retrieved from https://www.fcsl.edu/userfiles/files/Diaz.pdf

Galafassi, D., Kagan, S., Milkoreit, M., Heras, M., Bilodeau, C., Juarez-Bourke, S., Merrie, A., Guerrero, L., Pétursdóttir, G. \& Tàbara, J. D. (2018). Raising the temperature: the arts on a warming planet. Current Opinion in Environmental Sustainability, 31, 71-79. http://dx.doi.org/10.1016/j.cosust.2017.12.010

Gibson, R. (2010). The known world. TEXT Special Issue, 8, 1-11. Retrieved from http://www.textjournal.com.au/speciss/issue8/Gibson.pdf

Glade-Wright, R., (2016) Tidelines: Creative Vision, Ecology and the Tropics, eTropic, 15 (1), 15-25. DOI: http://dx.doi.org/10.25120/etropic.15.1.2016.3355

Glade-Wright, R., (2018) Microplastics Found in Human Embryo. Artwork display at AAS2018 'Life in an Age of Death' Australian Anthropological Society Annual Conference. James Cook University College of Arts, Society and Education, The Cairns Institute, Australia 4-7 December 2018.

Graham, G. (2005). Philosophy of the arts: An introduction to aesthetics. $3^{\text {rd }}$ ed. New York, NY: Routledge.

Hammer, J., Kraak, M. H. S., \& Parsons, J. R. (2012). Plastics in the Marine Environment: The Dark Side of a Modern Gift. Reviews of Environmental Contamination and Toxicology, 220, 1-44. https://doi.org/10.1007/978-1-4614-3414-6_1

Hulme, M. (2015). Climate and its changes: a cultural appraisal. Geography and Environment, 2 (1), 1-11. https://doi.org/10.1002/geo2.5

Jacobson, S. K., Seavey, J. R., \& Mueller, R. C. (2016). Integrated science and art education for creative climate change communication. Ecology and Society, 21 (3), 30. http://dx.doi.org/10.5751/ES-08626-210330 
Kindsvater, H., Dulvy, N., Horswill, C., Juan-Jorda. M., Mangel, M., \& Matthiopoulos, J. (2018). Overcoming the Data Crisis in Biodiversity Conservation. Trends in Ecology \& Evolution, 33 (9), 676-688. https://doi.org/10.1016/j.tree.2018.06.004

Klar, M., Gunnarsson, D., Prevodnik, A., Hedfors, C., \& Dahl, U. (2014).

Everything you (don't) want to know about plastics, Dhaka City Corporation, Dhaka. Retrieved from https://www.naturskyddsforeningen.se/sites/default/files/dokumentmedia/rapporter/Plastic-Report.pdf

Lebreton, L., Slat, B., Ferrari, F., Sainte-Rose, B., Aitken, J., Marthouse, R., Hajbane, S., Cunsolo, S., Schwarz, A., Levivier, A., Noble, K., Debeljak, P., Maral, H., Schoeneich-Argent, R., Brambini, R., \& Reisser, J. (2018). Evidence that the Great Pacific Garbage Patch is rapidly accumulating plastic. Scientific Reports, 8, (4666). https://doi.org/10.1038/s41598-018-22939-w

Liebezeit, G., \& Liebezeit, E. (2014). Synthetic particles as contaminants in German beers, Food Additives \& Contaminants: Part A, 31 (9), 1574-1578. https://doi.org/10.1080/19440049.2014.945099

Lockie, S. (2018). Opening introductory address. AAS2018 'Life in an Age of Death' Australian Anthropological Society Annual Conference. James Cook University College of Arts, Society and Education, The Cairns Institute, Australia 4-7 December.

Mendenhall, E. (2018). Oceans of plastic: A research agenda to propel policy development. Marine Policy, 96, 291-298. https://doi.org/10.1016/j.marpol.2018.05.005

Mishra, V. (1994). The Gothic Sublime. Albany: State University of New York Press.

Morgan, J. (1998). Toward an Organic Theory of the Gothic: Conceptualizing Horror. The Journal of Popular Culture, 32, 59-80. https://doi.org/10.1111/j.00223840.1998.3203 59.x

Moser, S. C. (2016). Reflections on climate change communication research and practice in the second decade of the 21st century: what more is there to say? WIREs Climate Change, 7 (3), 345-369. https://doi.org/10.1002/wcc.403

Nace, T. (2017). We're Now at a Million Plastic Bottles Per Minute - 91\% Of Which Are Not Recycled. Retrieved from https://www.forbes.com/sites/trevornace/2017/07/26/million-plastic-bottles-minute-91not-recycled/\#2ff21b8e292c

Ohlendorf, H.M., Risebrough, R.W., \& Vermeer, K. (1978). Exposure of marine birds to environmental pollutants - pubs.er.usgs.gov. Retrieved from https://archive.org/details/exposureofmarine00ohlerich

Reiss, J. (2019) (Ed.). Art theory and Practice in the Anthropocene. Retrieved from https://vernonpress.com/book/492

Rojas, J. (2018). Plastic Waste is Exponentially Filling our Oceans, but where are the Robots? Computer Science. Retrieved from https://arxiv.org/abs/1809.00798

Rees-Cheney, T. (2005). Getting the Words Right: 39 ways to improve your writing. $2^{\text {nd }}$ ed. Cincinnati: Writer's Digest Books.

Seltenrich, N. (2015). New link in the food chain? Marine plastic pollution and seafood safety. Environmental health perspectives, 123 (2), 34-41.

Shelley, M. W. (1818). Frankenstein: Florianópolis: UFSC, 2016. Gothic Digital Series. Retrieved from https://repositorio.ufsc.br/bitstream/handle/123456789/173238/Frankenstein.pdf?seq uence $=1$ \&isAllowed $=y$

Tsekos, A., \& Petsiou, C. A. (2018). Environment and Philosophy: The Aesthetics and the Natural Environment. Scientific Research, 4 (2), 13-21. Retrieved from https://www.scirp.org/journal/PaperInformation.aspx?paperlD=85222

Tyree, C., \& Morrison, D. (2017). Invisible-the Particles inside Us. Orb Media. Retrieved from https://orbmedia.org/stories/Invisibles_plastics/text 
Van Cauwenberghe, L., \& Janssen, C. (2014). Microplastics in bivalves cultured for human consumption. Environmental Pollution, 193, 65-70. https://doi.org/10.1016/j.envpol.2014.06.010

Waring, R. H., Harris, R. M., \& Mitchell, S. C. (2018). Plastic contamination of the food chain: A threat to human health? Maturitas, 115, 64-68. https://doi.org/10.1016/j.maturitas.2018.06.010

Wilcox, C., Van Sebille, E., \& Hardesty, B. D. (2015). Threat of plastic pollution to seabirds is global, pervasive, and increasing. Proceedings of the National Academy of Sciences of the United States of America, 112 (38), 11899-11904. doi: 10.1073/pnas.1502108112. 